
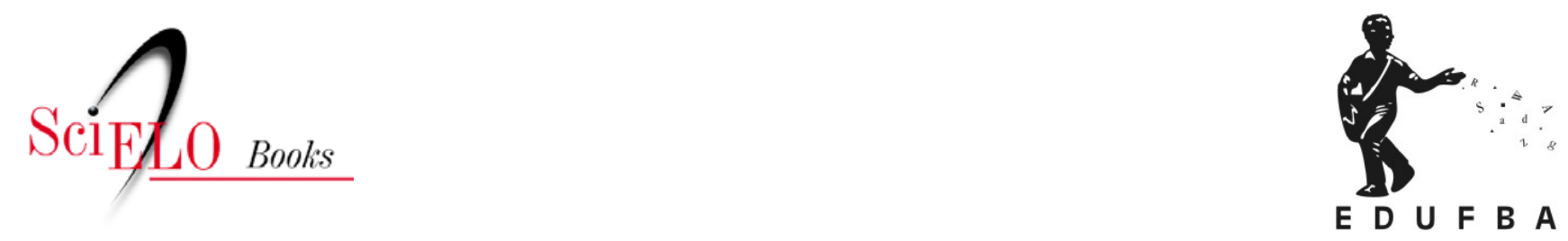

\title{
Deixa eu ver sua alma-Narrativa de si como política de si em escritos de Luiz Alberto Mendes
}

\author{
Denise Carrascosa
}

\section{SciELO Books / SciELO Livros / SciELO Libros}

CARRASCOSA, D. Deixa eu ver sua alma-Narrativa de si como política de si em escritos de Luiz Alberto Mendes. In: COELHO, M.T.Á.D., and CARVALHO FILHO, M.J., orgs. Prisões numa abordagem interdisciplinar [online]. Salvador: EDUFBA, 2012, pp. 197-214. ISBN 978-85-2321735-8. Available from: doi: 10.7476/9788523217358.013. Also available in ePUB from: http://books.scielo.org/id/7mkg8/epub/coelho-9788523217358.epub.

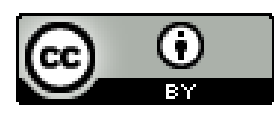

All the contents of this work, except where otherwise noted, is licensed under a Creative Commons Attribution 4.0 International license.

Todo o conteúdo deste trabalho, exceto quando houver ressalva, é publicado sob a licença Creative Commons Atribição 4.0. 


\section{Deixa eu ver sua alma- Narrativa de si como política de si em escritos de Luiz Alberto Mendes}

Denise Carrascosa

\section{Introdução}

No dia em que Luiz Alberto Mendes foi encarcerado na Casa de Detenção do Complexo do Carandiru como "primário" (e, portanto, mandado para o seu pavilhão 9), seu corpo já havia sido reincidentemente marcado por uma duríssima tecnologia disciplinar-prisional posta em prática nos juizados de menores, delegacias e DOI-CODIs ${ }^{1}$ da vida subterrânea do Estado de São Paulo entre as décadas de sessenta e setenta.

Era o ano de 1973 (estado ditatorial no Brasil) e, aos 21 anos, Mendes já fora interno do juizado de menores aos 11 ou 12 (1963 ou 1964), relatando ter ouvido de um delegado o seguinte: "Devíamos exterminar esses animaizinhos antes que se tornem um problema insolúvel para o futuro. Vai para o juizado e é provável que amanhã mesmo já esteja aí nas ruas atacando algum trabalhador”. (MENDES, 2001, p. 83)

No alojamento do juizado, depois de uma tentativa frustrada de fuga, "os funcionários pegaram pedaços de pau e bateram com

1 Destacamento de Operações de Informações do Centro de Operações de Defesa Interna - um dos aparelhos de repressão do Regime Militar Brasileiro, que funcionou como centro de aplicação de técnicas de tortura, entre os anos 1969 e 1980, 
vontade”. (MENDES, 2001, p. 84) Esta cena de castigo corporal, tendo em vista as tantas outras dos seus escritos, é narrada sem muitos detalhes:

Havia prazer neles em bater, parecia que nunca mais iriam parar. Quando decidiram que eu apanhara o suficiente, jogaram-me nu, dentro de um quartinho escuro. Estava todo quebrado, dolorido demais, querendo minha mãe. Ainda gritava por minha mãe quando me batiam, como uma criança. Adormeci, cansado, para acordar em seguida, sufocado pela água que um funcionário jogou em mim com um balde. (MENDES, 2001, p. 84-85)

No outro dia, de manhã cedo, um funcionário perguntou-lhe como estava, alegando não ter ajudado na surra. Luiz nos diz que fez que não o viu batendo. Pede suas roupas, porque morria de frio. O funcionário chama um colega que, assustado com o estado do menino, leva-o à enfermaria. Lá, ele finge estar pior do que realmente estava. Depois de três dias de enfermaria, volta ao alojamento, no qual:

Os funcionários olhavam caçadores. A vigilância redobrava em cima de mim. Ficaram me seguindo o tempo todo, não me perdiam de vista. Nem pensei mais em fugir, fiquei com o maior medo da surra que me prometiam, caso tentasse. Decidi esperar meu destino. (MENDES, 2001, p. 85)

Por uma perspectiva, os escritos de Luiz Alberto Mendes constituem reativações narrativas de algumas das constantes de sua vida que podemos ler no episódio resenhado acima: aprisionamento, fuga, castigo corporal, repetida sensação de vigilância e medo.

Tais elementos nos chegam mediados por uma decisão: a escrita da própria vida, tomada aos trinta e seis anos (1988) numa cela individual da Penitenciária do Estado de São Paulo, na qual Mendes fora novamente preso quatro anos depois de ter fugido.

Tendo em vista dois de seus livros e um conto, resultantes desse esforço de escrita de si mesmo (respectivamente Memórias de um sobrevivente, Às cegas e Cela forte), interessa-me, aqui, analisar as marcas deixadas pela dura tecnologia disciplinar-prisional vivida/ narrada, sobre a voz de Luiz Alberto Mendes e, mais ainda, pensar seus investimentos discursivos, estratégicos e, portanto, políticos no sentido de um retrabalho ativo sobre tais marcas, o que chamo (com clara extração foucaultiana), respectivamente: técnicas e políticas de si. 


\section{A prisão é uma coisa demasiado estúpida ${ }^{2}$}

Depois de muito tempo - mas o que era "muito tempo"? - comecei a procurar por mim mesmo na pessoa que dormia e acordava no chão daquele lugar odioso cuja imutabilidade impunha-se como prova de que não havia - nunca houvera - outros lugares. (VELOSO, 2004, p. 359, grifo nosso)

A forma-prisão como mecanismo disciplinar opera, entre outros efeitos, uma espécie de ruptura física e simbólica entre o sujeito aprisionado e suas unidades de atribuição de significado a si mesmo como sujeito sócio-histórico: o lugar onde mora, sua família, seu circuito de relações pessoais, suas ocupações, a organização temporal da rotina, as possibilidades de deslocamento espacial, o seu corpo.

Não é sem propósito que os relatos de indivíduos presos mencionam correspondências, encomendas (roupas, comidas, cigarros), "bondes", ${ }^{3}$ visitas de amigos, familiares e visitas íntimas sob uma atmosfera mista de ansiedade e alívio da tensão do encarceramento, a funcionar como válvulas de escape e reconexão com um mundo real.

Paradoxalmente, entretanto, dispositivos prisionais, como o isolamento em uma cela individual por vários dias consecutivos, têm a potência de reinscrever, em uma zona de tensão, a relação do indivíduo para consigo próprio, para com um espaço a si atribuível de "interioridade", "consciência”, "essência” ou "alma” - noções socialmente recorrentes quando se pensa uma unidade estável, imutável, eterna e bem guardada dentro de cada corpo individual, que o anima e torna transcendentalmente diverso dos demais. Se lermos Aristóteles nesse sentido, alguns fragmentos de sua Metafísica podem tornar-se bem atuais:

2 Da carta de Antônio Gramsci endereçada a "Querida Mamãe", do "Cárcere de Milão" em 12 de março de 1928: "A prisão é uma coisa demasiado estúpida; mas para mim seria ainda pior a desonra por fraqueza moral e por velhacaria. Por isso, a senhora não deve se alarmar e magoar muito, nem pensar nunca que eu esteja abatido e desesperado. Deve ter paciência e, em quaisquer circunstâncias, não acreditar nas lorotas que possam publicar a meu respeito. Espero que já tenha recebido todas as minhas cartas precedentes. Renovo os votos mais afetuosos pelo seu aniversário e abraço-a ternamente. Nino". (GRAMSCI, 1978, p. 108)

3 O "bonde" é a chegada de novos detentos a uma instituição prisional, que sempre anuncia notícias do mundo exterior, e é aguardado com ansiedade pelos que lá se encontram presos (a questão recorrente dos celulares nos presídios brasileiros, tratada midiaticamente apenas do ponto de vista da instrumentalização do crime, pode ser pensada como sintomática da ruptura físico-simbólica de que trato aqui). 
Parece, além disso, impossível que existam separadamente a substância e aquilo de que ela é substância: neste caso, as idéias, que são as substâncias das coisas, como existiriam separadas delas? No Fédon, porém, afirma-se que as idéias são causas do ser e do devir. Todavia, ainda que as idéias existam, os seres que delas participam não são gerados se não houver um primeiro motor. (ARISTÓTELES, 1979, p. 32)

O "si" do olhar do sujeito encarcerado para si mesmo passa a constituir uma unidade complexa formada por aquilo que resta de "mim" quando absolutamente despido de tudo que me fazia significar como sujeito e, ao mesmo tempo, por aquilo que sempre esteve em "mim" e que, entretanto, eu não conheço, a minha "substância". O isolamento carcerário pode, assim, instaurar um movimento de aproximação do sujeito com esse espaço de imaginária interioridade chamado, entre outros epítetos, de "alma".

No conto Cela forte, Luiz Alberto Mendes narra que, em maio de 1973, aguardava a hora da contagem dos presos, deitado em sua cela, lendo Luzia homem "como todo preso, pronto para ser contado. Almas concretas, densas até os ossos” (MENDES, 2005b, p. 109), quando cerca de dez guardas armados de cano de ferro invadiram sua cela, revistaram-na e mandaram que ele abaixasse o calção, levantasse "o saco" e agachasse três vezes:

Eu parecia uma mola para baixo e para cima. Provavelmente pensavam que escondesse uma metralhadora, ou sei lá o que, no cu. Era extremamente humilhante. Me encolhi, com meu exército de palavras desmantelado e minha alma menos minha. (MENDES, 2005b, p. 109)

Parece haver aí enunciado um espaço híbrido de relações de força entre aquilo que lhe resta de próprio em uma cena de intervenção quase absoluta em seu espaço individual (cela/corpo) - "minha alma" - e um lugar de seqüestro (potencial cativeiro desta alma): "alma menos minha”.

Em sua pesquisa sobre a história das prisões, Michel Foucault afirma que a punição penal se metamorfoseia modernamente (século XVIII) a partir de uma penalidade supliciante do corpo em direção a uma "penalidade do incorporal": 
Se não é mais ao corpo que se dirige a punição, em suas formas mais duras, sobre o que, então, se exerce? [...] Pois não é mais o corpo, é a alma. À expiação que tripudia sobre o corpo deve suceder um castigo que atue, profundamente, sobre o coração, o intelecto, a vontade, as disposições. (FOUCAULT, 2005, p. 18)

No entanto, se por um instante pudermos pensar em articulação do investimento simultâneo do sistema prisional moderno sobre o corpo do preso e sobre sua "alma" de modo supliciante (referido pelo mesmo texto foucaultiano), este seria o instante do "isolamento" como técnica de castigo físico e simbólico (nas "Isoladas", "Celas Fortes" e "Masmorras" do sistema).

E cela-forte, ali, era forte mesmo. Ficava-se isolado em uma cela, só de calção, sem contato com ninguém. E ainda havia a cafua. Um quarto escuro e todo trancado, isolado da prisão. Esse era o lugar que todos mais temiam. A escuridão apavorava. (MENDES, 2001, p. 159)

O pânico se apossou de mim. A cela estava nua como eu. Não havia nada ali. As paredes vertiam água. O chão era de caquinhos de cerâmica, geladíssimo. O tempo estava gelado, eu já tremia de medo e frio desde os primeiros instantes ali. (MENDES, 2001, p. 429)

Apenas quando me deitei, esgotado de cansaço, no chão gelado, é que fui estar plenamente consciente de mim. Senti o corpo e o espírito quebrados. (MENDES, 2001, p. 419)

Fiquei apenas eu ali. Foi difícil a solidão, cheguei a chorar várias vezes e ainda querer minha mãe. Os anos haviam se passado, e eu ainda era um menino querendo sua mãe. (MENDES, 2001, p. 420)

Um dos efeitos gerados por essa técnica de despojamento de tudo que faça o indivíduo significar socialmente, inclusive de sua relação simbólica com o próprio corpo, constitui a potencialização do sentimento de solidão. O sujeito, fora de um tempo e de um espaço que lhe geram um olhar de reconhecimento de si mediado pela vida social, procura um "si" outro, um "si" em silêncio absoluto de outras vozes que não sejam a sua própria.

Atravessada por uma série de experiências de isolamento físico, a voz narrativa de Mendes, na construção de um personagem para si, é reiteradamente marcada por esta referência: a solidão, retraçada ao período de sua infância: 
Uma das lembranças mais doloridas era a solidão em que eu vivia em casa e na creche. Tive muito poucos amigos [...] Muitas vezes minha mãe se atrasava, era longe de casa a creche, eu me desesperava. Ficava ali no portão chorando, sentindo-me miseravelmente abandonado. (MENDES, 2001, p. 20)

Esta sensação de solidão intensa, como marca de uma voz que busca uma espécie de "si" em uma história de vida pessoal, articula-se narrativamente a certos medos que posicionam o personagem-criança em um cenário de insegurança existencial: "Esse era o maior medo de minha mãe: o despejo. Não ter onde morar. Vivia apavorada com tal possibilidade, que, diga-se de passagem, era bem concreta. Uma ameaça constante, mensal”. (MENDES, 2001, p. 20)

A figura paterna, responsável social pela manutenção econômica da família - o menino Luiz, a mãe que cuidava da casa e o pai que oscilava entre o emprego e o desemprego - é repetidamente mostrado em cenas como a que segue:

Ele chegava, minha mãe esquentava a comida. Mal começava a comer e já desmaiava de cara no prato, de tão bêbado que estava. Eu, pequeno, dona Eida, pequena também, tínhamos que arrastá-lo da cozinha até o quarto. Depois, com toda dificuldade do mundo, colocá-lo na cama, despi-lo e cobri-lo. Era muito pesado e ficava dando tapas no ar, semiconsciente. Quando um deles pegava em um de nós, voávamos longe. (MENDES, 2001, p. 21)

À força, muitas vezes truculenta do pai, opõe-se o corpo frágil da mãe, fonte da tênue zona de confiança e segurança afetiva que é delineada pela narrativa:

Eu e dona Eida éramos muito apegados. Sentíamos que, na verdade, só tínhamos um ao outro no mundo. Ele não participava desse círculo fechado. Jamais fez por merecer. Minha mãe escondia muitas de minhas traquinagens. Sabia que, se ele soubesse, eu seria massacrado. Aquela mulher era muito delicada, extremamente feminina, eu a amava a ponto de chorar às vezes, só de pensar nela. Fisicamente era muito pequena: tivera meningite aos doze anos e não crescera mais. (MENDES, 2001, p. 20)

Esta figura materna funciona sempre como um débil vínculo entre o sujeito Luiz Alberto Mendes e o fora do mundo do "crime". Nas margens da ideia de delinquência como geradora da identidade do narrador que se escreve, dona Eida aparece sempre para lhe visitar 
quando está preso, levar roupas, dinheiro, notícias do mundo exterior, carinho e vontades de entrega a uma vida social estável, com emprego, esposa e filhos.

Algumas das muitas mulheres que são postas em cenas diversas ao longo da vida de Mendes reativam essa frágil zona de segurança afetiva, que parece ser sempre intensa em termos de atividades sísmicas, sempre desenhada como se fosse chão de gelo fino sob seus pés, prestes a rachar. A última dessas mulheres que nos é apresentada por seus escritos é Magda:

Chegava a hora de pensar em ser honesto. Não importava que todos roubassem. Eu não queria mais isso pra mim. Queria um pacto de paz com o mundo. Precisava de paz para amar e ser feliz. Queria ter algo além de palavra e coração para oferecer à namorada. Magda me levava a pensar na honestidade como princípio. Ela queria um companheiro que procedesse dentro de seus padrões. Eu queria ter orgulho de vencer, superar e ultrapassar. (MENDES, 2005a, p. 253)

Esse espaço intervalar em uma vida marcada pelo signo da delinquência também funciona em três ou quatro cenas de encontro com seu pai. Ao completar 18 anos, preso em um Instituto de internamento para menores infratores em Mogi-Mirim, Mendes afirma odiar o pai, que seria o responsável por sua manutenção ali, cogitando, inclusive a possibilidade de matá-lo: “Só matando-o, então, me livraria?” (MENDES, 2001, p. 187) Dois parágrafos depois, a voz narrativa nos fala da visita desse pai como um fato inédito e surpreendente até aquele ponto de sua vida:

Pedi a benção de meu pai, beijei sua mão forte e grossa. Naquele momento eu o amei, senti nele um pai, pela primeira vez em minha vida. Havia segurança, força e autoridade nele, e aquilo me emocionava demais. Eu jamais soubera o que era um pai mesmo. (MENDES, 2001, p. 187)

A essas radicais oscilações de atitudes e desejos do sujeito em espaços curtíssimos de tempo, sejam os do narrado ou da própria narrativa, podemos conectar os escritos de epílogo de Memórias de um sobrevivente e Às cegas, na medida em que funcionam como um olhar retroativo sobre e, de certa forma, reativador da articulação entre viva vivida e vida escrita: 
Passaram-se mais de vinte anos do final do relato que fiz de minha vida. Muita água rolou por baixo da ponte, nesse tempo. Daria para fazer um novo livro. Talvez até venha a fazê-lo, não se sabe do futuro. A intenção é escrever sempre e para sempre. Mas não sei... a vida me ensinou a nunca esperar fluidez contínua, e sim descontinuidade, tanto na vida de cada um, como na de todos em geral. (MENDES, 2001, p. 471)

Por exemplo, Magda não permaneceu. Me abandonou, mais uma vez. Motivos? Os mesmos de sempre. Queria presença, e eu não podia. Queria uma segurança que nunca tive nem pra mim. (MENDES, 2005a, p. 355).

A relação (narrativa) desse sujeito com os fatos de sua própria vida (elementos selecionados, formas de organização e auto-análise) parece marcada, desse modo, por uma constante sensação de insegurança em frequência com a solidão como efeito do isolamento prisional, a se projetar tanto sobre a subjetividade descontínua que resulta da narrativa, quanto sobre a dinâmica narrativa que a engendra como técnica de subjetivação. Isto é: parece atuante sobre os escritos de Luiz Alberto Mendes um certo dispositivo de atenuação das conexões entre o que ele procura construir como um lugar para "si" e outras unidades sociais de atribuição de sentido ao sujeito, o que resulta em uma instabilidade constante desse mesmo "lugar para si" e de seu processo de construção: subjetivação via narrativa da própria vida.

Se pensado esse processo de subjetivação sob o enfoque que dá Anthony Giddens à "construção do eu" como um potencial "conseqüência da modernidade" ou ao que chama de "modernidade radicalizada" como possibilitadora de "processos ativos de auto-identidade", através das relações de confiança em seus "sistemas abstratos" e "mutualidade" e "intimidade" das "relações de confiança pessoal" (GIDDENS, 1991, p. 116-117) talvez possamos hipotetizar que a técnica punitiva do isolamento do preso engendra uma espécie de curto-circuito nos processos modernos de construção de um sentido estável para o "eu”, na medida em que instaura a procura de um "si mesmo" mediada pela solidão, pela violenta ruptura com elementos sociorreferenciais mais estáveis de produção de sentido.

Operando sob esta ótica, os escritos de Luiz Alberto Mendes podem ser lidos como a escolha de uma forma, ou melhor, uma técnica, talvez ainda uma política para lidar com uma dupla e violenta, porque 
abrupta, pressão da tecnologia disciplinar-prisional sobre o sujeito à margem social: o isolamento como sequestro das possibilidades sociais de atribuição de um sentido mais estável a si mesmo, bem como intensificação de uma relação com um lugar a ser construído para esse "si”, mediada por uma solidão e instabilidade profundas.

Na dinâmica oscilante entre a técnica de despersonalização que implica a superlotação das celas e a de individuação do isolamento, ambas as experiências narradas por Luiz Alberto Mendes, o medo e a intensificação do pensamento são constantemente referidos:

$\mathrm{Na}$ cela individual, com tempo para refletir, aos poucos minha mente começou a entrar em parafuso [...] No tambor das lembranças, as palavras disparavam irreversíveis. Eu sentia muito medo de ser incontrolável, irracional. Medo de que me dominar estivesse além de minhas possibilidades. (MENDES, 2005a, p. 236)

O ano era o de 1988 e Luiz Alberto Mendes estava em uma cela individual da Penitenciária do Estado de São Paulo, frustrado por não ter aproveitado a oportunidade de formar-se pela PUC-SP em Direito ou História, de não estar fora da prisão, "[...] vivendo em sociedade. Casado talvez, com filhos, num lar. Minha mãe feliz comigo”. (MENDES, 2005a, p. 236) A cena que segue parece um ponto fundamental o suficiente para justificar a longa citação:

Comecei a ver minha vida como uma série de conseqüências. As causas, eu não percebia. Quando dava por mim, já estava nas conseqüências. A verdade que devia ser assumida: eu não tinha controle sobre a minha existência. Vivia uma roda-viva, cujas conseqüências desencadeavam causas que geravam outras conseqüências. E eu, no meio, em espaços reduzidos, travado. Lutando, lutando para boiar na tábua escorregadia do meu presente. Passado movediço, futuro ignorado.

Eu queria tornar compreensível à razão esse processo. Refletia, vasculhava e me perdia em pensamentos capilares. Busquei, com unhas e dentes, um método. Durante o tempo em que estudei, o melhor método para aprender fora a escrita. Eu escrevia tudo o que entendia e assim assimilava definitivamente.

A idéia de escrever minha vida foi automática. Escrever para mim mesmo, para ninguém mais. Sem receio de ser punido ou censurado. Precisava entender o que havia acontecido. Era isso. Iria escrever minha história para me conhecer. (MENDES, 2005a, p. 237) 
Neste ponto de Às cegas, Luiz Alberto Mendes coloca em narrativa uma cena de gênese de Memórias de um sobrevivente, que teria sido escrito durante cinco meses de sofrido "mergulho em seu passado", a partir, inclusive, de notas que tomara a sua mãe sobre a história de seus pais e sua infância. "Descobre", assim, que fora criado "na base do chicote", uma criança "melancólica, solitária e muito infeliz": "via-me na figura daquele menino e me desconhecia. Às vezes ele era eu mesmo, e chorava me descrevendo, com profunda piedade daquele garoto”. (MENDES, 2005a, p. 238)

Na adolescência, passara "fome, frio, solidão, terror, aventura, sexo, vaidades e loucuras inexplicáveis. Revivi um tumulto interior impossível de ser controlado ou contido nas quatro paredes da minha cela”. (MENDES, 2005a, p. 238)

A partir da referência à fase em que começara a "ser preso seriamente”, menciona "Torturas e sevícias. Espancamentos, estiletadas, borrachadas, nas prisões para menores infratores". (MENDES, 2005a, p. 239) À "fase” das armas, assaltos e drogas, seguem-se a tortura sistemática, a chegada à Casa de Detenção, à Penitenciária do Estado e a experiência da cela-forte. Na seqüência, aparecem "o maior dos amigos" - Henrique Moreno, que lhe leva à paixão pela literatura - e "o primeiro amor verdadeiro" - Eneida, que lhe faz estudar com "seriedade, responsabilidade”. (MENDES, 2005a, p. 239)

A retomada em flashes dos cinco meses de escrita de uma parcela de sua vida - "minha história até os vinte e sete anos" (MENDES, 2005a, p. 241) - opera pela narrativização das reações e motivações de um sujeito encarcerado na trajetória de aproximação a uma certa "verdade de si” que só passa a lhe ser acessível pelo "método" da escrita. Em Às cegas, o Luiz Alberto Mendes-ladrão-detento torna-se o Luiz Alberto Mendes-escritor-senhor-de-sua-existência, no espaço desse trecho narrativo e em suas extrapolações: "Cada linha foi extraída como que com as unhas, de grossas paredes. Parei muitas vezes. Ficava dias sem escrever. Em recuperação. Quando me sentia forte, retomava”. (MENDES, 2005a, p. 239)

Contracenam, ali, um sujeito oprimido/produzido por uma trajetória-tecnologia de produção social de marginalização e um sujeito que toma consciência dela via escrita de si. Contra o pano de fundo de uma cela individual na Penitenciária do Estado, dois personagens 
se projetam: o personagem-resultado caótico de uma vida desregrada e o personagem-atividade que decide impor-se um método de domínio de si, que levasse a uma aprendizagem sobre si mesmo, a partir do controle dos tempos vividos/a viver - passado, presente, futuro, de suas relações entre causas e conseqüências, ou seja, um método narrativo de escrita/aprendizagem de si.

Quanto à escrita como técnica de produção de uma identidade para si, em uma série de estudos sobre textos regulamentadores de práticas da cultura greco-romana circulantes nos dois primeiros séculos da chamada "era cristã", Michel Foucault examina aquilo que chama de "cultura de si" como motivada, entre outros fatores, por uma necessidade de aprendizagem de exercício de domínio sobre si diante dos acontecimentos. De uma passagem extraída de Sêneca, que cita Demétrius, sublinha:

[...] devemos nos exercitar como faz um atleta; este não aprende todos os movimentos possíveis, não tenta fazer proezas inúteis; prepara-se para alguns movimentos necessários à luta para triunfar sobre seus adversários [...] Como um bom lutador, devemos aprender exclusivamente aquilo que nos permitirá resistir aos acontecimentos que se podem produzir; devemos aprender a não nos deixar perturbar por eles, a não nos deixar levar pelas emoções que eles poderiam suscitar em nós. (FOUCAULT, 1997, p. 126-127)

Para fazer face à potencialidade futura dos acontecimentos, seria preciso dispor de um equipamento de "discursos verdadeiros" sobre o mundo que estivesse sempre à mão, fixado ao "espírito", constituindo métodos dessa apropriação: exercícios de memorização do que fora aprendido, a boa escuta como direcionamento da atenção e a escrita pessoal em "notas das leituras, conversas, reflexões que se ouvem ou que se fazem a si mesmo". (FOUCAULT, 1997, p. 127-129)

A escrita como exercício constituiria um "treino de si por si mesmo”, uma forma de manutenção dos pensamentos noite e dia à disposição, postos como objeto de conversações consigo mesmo e com os outros, um trabalho do pensamento sobre ele mesmo a reativar aquilo que sabe a fim de enfrentar o real, mediante uma "elaboração dos discursos recebidos e reconhecidos como verdadeiros em princípios racionais de ação", função, enfim, na expressão extraída de Plutarco, etopoiética. (FOUCAULT, 2004b, p. 146-147) 
Se posto entre parêntesis o hiato temporal que nos separa historicamente dos dois primeiros séculos do império romano, poderíamos afirmar que, em Às cegas, Luiz Alberto Mendes apresenta-se como um personagem que pratica esse exercício de si como técnica de produção ativa de uma identidade:

$\mathrm{Na}$ época da escravidão, os africanos, depois de um tempo nas fazendas e engenhos, construíam uma identidade, além da de escravos. Então eram ferreiros, mestres de engenho, domadores [...]. O mesmo se dá com alguns de nós. Criamos uma identidade além da de presos. Então somos escriturários, professores, marceneiros, pedreiros, encanadores $[\ldots]$

Essa a minha diferença. Eu era alguém na multidão. Fazia exercícios de escrita elaborando textos. (MENDES, 2005a, p. 276)

A "verdade narrativa" do "eu" que resulta do processo de escrita de si é convertida em um ethos de ação potencialmente geradora de uma identidade a si para confronto com o seu real: o real da solidão como dispositivo de dissolução subjetiva do preso e, ao mesmo tempo, como técnica de suscetibilização à assunção da posição discursiva de "preso".

Em face dessa relação narrativa de si para consigo mesmo, do exercício encenado e estratégico de um controle sobre sua própria identidade, é que procuro pensar técnicas que atuam em conexão com a "escrita de si” de Luiz Alberto Mendes, tomada como flagrante de relações de força entre técnicas de sujeição do criminoso-detento e técnicas ativas, portanto políticas, de subjetivação.

Se pensarmos, com auxílio Lyotard (2004), as noções de "modernidade" e "pós-modernidade" como espaços narrativos ${ }^{4}$ e, para além dessa idéia, como espaços narrativos que habitamos com nossos corpos e nossos hábitos, podemos exercitar a idéia do sujeito como corpo que procura uma casa, mesmo que em constante reforma.

O "sujeito descentrado" da pós-modernidade, como conceito (HALL, 2003, p. 46), opera pela ideia de uma precariedade constante

4 A teorização de Jean-François Lyotard sobre a "condição pós-moderna" tem como uma de suas idéias mais difundidas a do declínio dos grandes relatos e de seu poder unificador e legitimador na cultura contemporânea da sociedade pós-industrial, que Lyotard chama de “cultura pós-moderna”. Quanto ao problema do sujeito como elemento desta cultura, Lyotard propõe: "Nesta disseminação dos jogos de linguagem, é o próprio sujeito social que parece dissolver-se. O vínculo social é de linguagem, mas ele não é constituído de uma única fibra.é uma tecitura onde se cruzam pelo menos dois tipos, na realidade um número indeterminado de jogos de linguagem que obedecem a regras diferentes". (LYOTARD, 2004, p. 73) 
das narrativas que o atravessam. No entanto, para os sujeitos produzidos pela tecnologia discursiva que gera a posição de sujeito "criminoso" potente para interpelar o indivíduo através de suas próprias práticas de si e pela tecnologia disciplinar-prisional, que atravessa o detento com isolamento, tortura do corpo e vigilância, para esse sujeito que é interpelado a produzir-se a si na injunção criminoso-detento, construir, ter uma casa feita de narrativas do eu é um gesto no mínimo, político. Constitui uma política de si, uma política de vida.

Como já proposto anteriormente, a potência de interpelação da ideia de "criminoso" que, olhada de perto, também é narrativamente formulada, constrói uma posição discursiva que pode servir como lugar a ser ocupado pelo indivíduo que vive nas margens da ordem social, tanto do ponto de vista econômico, quanto histórico-cultural. Esta ideia de "sujeito criminoso" como condição estável a se encaixar sobre estes indivíduos pode ser pensada como um certo tipo de tecnologia de si potencialmente produtora de sujeitos socialmente "marginais" que se identificam com esta "condição", executando performances sociais em acordo com seus jogos discursivos.

Já as "técnicas de si" investidas contra a articulação corpo/alma do indivíduo preso remetem seus processos de subjetivação para uma zona "marginal", aqui usada no sentido derridiano de "margens" como "tecido de diferenças de forças sem nenhum centro de referência presente”, mas também como "uma inesgotável reserva". (DERRIDA, 1991, p. 25-26) Nesse sentido, o isolamento e a tortura do corpo, por exemplo, parecem funcionar como uma instauração de uma possibilidade de relação com si mesmo nessa zona de "margens", posto que desmembrada dos elementos que fazem o sujeito significar socialmente e a si mesmo.

Visto o problema a partir dessas perspectivas, a apropriação dessas técnicas diferencialmente "marginalizantes" da relação de um indivíduo com o movimento de produção de uma condição de sujeito para si e seu uso como uma "política de si”, de forma ativa, pode significar uma pressão pontual sobre a produção de sujeitos "abjetos" do ponto de vista social e simbólico, a forçar, para usar o pensamento de Judith Butler, "uma rearticulação radical daquilo que pode ser legitimamente considerado como corpos que pesam, como formas de viver que contam como "vida", como vidas que vale a pena proteger, como vidas que 
vale a pena salvar, como vidas que vale a pena prantear”. (BUTLER, 2001, p. 171)

Para citar Canclini quando fala de um outro quadro de "marginalização", a dos imigrantes e sua condição intercultural e transnacional: "Para eles, ser sujeito tem a ver com a busca de novas formas de pertencer, ter direitos e enfrentar violências". (CANCLINI, 2005, p. 205)

A partir da encenação de um eu esfacelado, produzido nas margens pelas técnicas que promovem uma relação dele consigo mesmo, parece que Luiz Alberto Mendes constrói para si uma casa feita de narrativas que lhe emprestam, para além de uma identidade provisória, uma aprendizagem de si potente para que possa ter à mão a sua própria "alma" - "alma como algo de móvel [...] algo que pode ser agitado, atingível pelo exterior”. (FOUCAULT, 2004a, p. 59)

Se assistirmos, por este viés, a entrevista de Mendes, já em liberdade, no programa Provocações, exibido pela TVE em 2007, nos chamará atenção o fato de que, à investida de Antônio Abujamra sobre uma possível auto-definição, Luiz Alberto Mendes dispara sem pausas:

Eu sou o produto dos meus fracassos. Eu fracassei a minha vida toda. Esses fracassos foram me construindo. Nós somos a somatória do que fizemos de nós. Eu fui me construindo através daquilo que eu tentei e não consegui. E chega um ponto que eu tenho e consigo. A vontade é imperiosa. Tudo a que eu me dediquei com vontade, eu cheguei. Eu acreditei em mim. Quando eu comecei a acreditar em mim, eu resolvi minha vida. (MENDES, 2007)

A escrita de si vista como técnica de produzir-se, de ter-se a si mesmo, no âmbito operacional da subjetivação, passa por uma relação de aprendizado útil de si que potencialize o uso estratégico de uma identidade, ainda que provisória, desterritorializada narrativamente.

Ambos os epílogos dos livros que aqui foram lidos, Memórias de um sobrevivente e Às cegas, tratam desse aprendizado: "Aprendi algumas coisas sobre mim"; (MENDES, 2001, p. 474) "Aprendemos sozinhos a nos virar diante da dor, cada um a seu modo"; (MENDES, 2001 p. 475) "Claro que há mazelas, hábitos e nervos em frangalhos, ninguém vive o que vivi impunemente”; (MENDES, 2001, p. 477) "Há uma tristeza profunda. Constato que o Brasil evoluiu muito da minha infância e adolescência até agora. Mas, em termos sociais, parece que as coisas continuam as mesmas”; MENDES, 2001, p. 477) “[...] mas 
também não vou mais seguir caminhos que já se provaram - exaustivamente - de dor. Mas também não vou dar mole, quero mais que simplesmente estar vivo (MENDES, 2001, p. 478) e, finalmente:

Vivi, e num mundo de homens estilhaçados. O medo permeava, e tinha cheiro de flores molhadas, surdamente pisadas à porta de cemitérios. Mas mesmo assim existi, e com intensidade.

A cada momento signifiquei de alguma maneira. (MENDES, 2005a, p. 356)

O aprendizado mediado pelo processo de escrita de si, a partir dos fragmentos selecionados acima, não constitui apenas um aprender com a memória narrativa do passado para agir no presente, consiste ainda um significar diferencial, uma possibilidade de produzir-se a si mesmo como sujeito que existe diferencialmente. Nesse sentido, a escrita de si funciona como "método" (a palavra é do próprio Mendes) de subjetivação ativa, de produção de uma "alma” escrita que pode ser lida, apesar de suas desterritorializações e por conta delas.

Pois, o fictício que comporta a ideia de sujeito segundo Nietzsche - "Não há nem espírito, nem razão, nem pensamento, nem consciência, nem alma, nem vontade, nem verdade: estas são simplesmente ficções inutilizáveis" (NIETZSCHE, 2005, p. 238) - pode vir a ser utilizável politicamente pela autoprodução de um indivíduo que, ainda que pontual e estrategicamente, possa tornar-se senhor de si, o "homem bravo" que aparece, por exemplo, na Ética aristotélica.

[...] Porque, exatamente como os membros paralisados se voltam para a esquerda quando procuramos movê-los para a direita, a mesma coisa sucede na alma: os impulsos dos incontinentes movem-se em direções contrárias. Com uma diferença, porém: enquanto, no corpo, vemos aquilo que se desvia na direção certa, na alma não podemos vê-lo.

Apesar disso, devemos admitir que também na alma existe qualquer coisa contrária ao princípio racional, qualquer coisa que lhe resiste e se opõe a ele. Em que sentido esse elemento se distingue dos outros, é uma questão que não nos interessa. Nem sequer parece ele participar de um princípio racional, como dissemos. Seja como for, no homem continente ele obedece ao referido princípio; e é de presumir que no temperante e no bravo seja mais obediente ainda, pois em tais homens ele fala, a respeito de todas as coisas, com a mesma voz que o princípio racional. (ARISTÓTELES, 1979, p. 64) 
"Com uma diferença, porém": o homem "bravo" que se faz ler como resultante dos escritos de Luiz Alberto Mendes, diversamente daquele que exerce um domínio central e absoluto sobre as linhas de fuga de sua "alma-substância”, passa a "ser" em narrativa, em processo, em deslocamento contínuo.

A contrapelo da operação de invenção da "alma" do sujeito "criminoso-hediondo", resultado de um "ser" irremediavelmente preso nas malhas discursivas e tecnológicas do poder de marginalização, a escrita de si, a partir dos escritos de Luiz Alberto Mendes, pode ser pensada contemporaneamente como política de si" na medida de sua dinâmica como conjunto de dispositivos a engendrar a produção ativa do sujeito, dentre os quais: a) a aprendizagem estratégica das técnicas de sujeição das relações de poder; b) a instauração de relações dinâmicas nas porosidades que separam e conectam narrativamente "presente" e "passado", no sentido de uma potencialização do presente que se projete sobre o processo de subjetivação; c) a gestualidade de encenação de um sujeito que se expressa no conjunto de posicionamentos discursivos potente para elidir o efeito de dissolução das operações marginalizantes.

Neste ponto, portanto, podemos pensar a narrativa de si, enquanto política de si, como uma das técnicas de subjetivação possíveis no âmbito dos vetores de força que atravessam os indivíduos, na medida em que operacionaliza a sua relação com uma série de pontos a serem ocupados nos espaços sociais de gestos, idéias, atitudes, pensamentos, em uma palavra: performances que os tornam plausíveis como sujeito.

Disso resulta conseguirmos pensar a ideia de sujeito, enquanto resultante do processo de escrita de si como uma zona de intensidades legível, conjunto de gestualidades e embates visíveis, contornável pelo gesto narrativo e pela nomeação autoral: "Aqui, apenas conto o que vivenciei. Não é testemunho ou tentativa de justificar. O fato é que sou o que vivi”. (MENDES, 2005a, p. 356, grifo nosso)

A injunção entre "contar" e "ser" engendra, assim, nos processos técnico-políticos da produção de "si”, uma alma-superfície que se deixa ver, que se deixa tocar, como espaço difuso, estratégico, fugidio, entretanto existente, de um indivíduo que se produz ativamente nas "margens" e para além delas. 


\section{Referências}

ARISTÓTELES. Metafísica: livro I e livro II; Ética a Nicômaco, Poética.

Tradução Vicenzo Cocco et al. São Paulo: Abril Cultural, 1979. (Coleção Os Pensadores).

BUTLER, Judith. Bodies that matter: on the discursive limits of "sex". New York, London: Routledge, 1993.

. Corpos que pesam: sobre os limites discursivos do "sexo". In: LOURO, Guacira Lopes (Org.). O corpo educado: pedagogias da sexualidade. Tradução Tomaz Tadeu da Silva. 2.ed. Belo Horizonte: Autêntica, 2001.

CANCLINI, Nestor García. Diferentes, desiguais e desconectados. Tradução Luiz Sérgio Henriques. Rio de Janeiro: UFRJ, 2005.

DERRIDA, Jacques. Margens da filosofia. Tradução Joaquim Torres Costa e Antônio M. Magalhães. Campinas, São Paulo: Papirus, 1991.

FOUCAULT, Michel. A hermenêutica do sujeito. Tradução Márcio Alves da Fonseca et al. São Paulo: Martins Fontes, 2004a.

. Ética, sexualidade, política. Tradução Elisa Monteiro et al. Rio de Janeiro: Forense Universitária, 2004b.

. Resumo dos Cursos do Collège de France (1970-1982). Tradução

Andréa Daher. Rio de Janeiro: Jorge Zahar, 1997. 2005.

. Vigiar e punir: nascimento da prisão. 30. ed. Petrópolis: Vozes,

GIDDENS, Anthony. As conseqüências da modernidade. Tradução Raul Fiker. São Paulo: UNESP, 1991.

GRAMSCI, Antônio. Cartas do cárcere. Tradução Noênio Spínola. 2. ed. Rio de Janeiro: Civilização Brasileira, 1978.

HALL, Stuart. A identidade cultural na pós-modernidade. Tradução Tomaz Tadeu da Silva et al. 7. ed. Rio de Janeiro: DP\&A, 2003.

LYOTARD, Jean-François. A condição pós-moderna. Tradução Ricardo Corrêa Barbosa. 8. ed. Rio de Janeiro: José Olympio, 2004.

MENDES, Luiz Alberto. Às cegas. São Paulo: Cia das Letras, 2005a. . Cela forte. In: FERRÉZ (Org.). Literatura marginal: talentos da escrita periférica. Rio de Janeiro: Agir, 2005b.

MENDES, Luiz Alberto. Entrevista. In: Provocações. Direção Antônio Abujamra) Programas 345 e 346, exibidos pela TVE em 07 nov. 2007 e 14 nov. 2007. 
. Memórias de um sobrevivente. São Paulo: Cia das Letras, 2001.

NIETZSCHE, Friedrich. Vontade de potência: parte 2. Tradução Mário D. Ferreira Santos. São Paulo: Escala, 2005. (Coleção Mestres Pensadores).

VELOSO, Caetano. Verdade tropical. São Paulo: Cia das Letras, 2004. 